\title{
Characteristics of a birnavirus isolated from cultured sand goby Oxyeleotris marmoratus
}

\author{
R. P. Hedrick ${ }^{1, *}$, W. D. Eaton ${ }^{1}$, J. L. Fryer ${ }^{2}$, W. G. Groberg, Jr. ${ }^{2}$ \& S. Boonyaratapalin ${ }^{3}$ \\ ${ }^{1}$ Aquaculture Program, Department of Medicine, School of Veterinary Medicine, University of California, Davis, California \\ 95616, USA \\ ${ }^{2}$ Department of Microbiology, Oregon State University, Corvallis, Oregon 97331, USA \\ ${ }^{3}$ National Inland Fisheries Institute, Bangkhen, Bangkok, Thailand
}

\begin{abstract}
A virus (SGV) was isolated from sand goby Oxyeleotris marmoratus with ulcer disease reared in freshwater cages in Thailand. The virus was typical of members of the aquatic birnaviruses but it possessed phenotypic, serological and biochemical properties that distinguished it from previously described viruses of the Birnaviridae. Serologically, the virus is distinct from the described strains of infectious pancreatic necrosis virus (IPNV) and possesses the capability of replicating in several cell lines from warm water fishes at $30^{\circ} \mathrm{C}$. The use of rapid double-stranded RNA analyses and the immunoprecipitation of radio-labeled virion polypeptides demonstrated the unique biochemical nature of SGV and established the value of these techniques for strain identification of birnaviruses.
\end{abstract}

\section{INTRODUCTION}

Viral examinations of various lots of fish in Thailand were conducted as part of an investigation into the cause of a widespread and lethal ulcerative disease in wild and cultured fish. The disease was initially observed in fish populations in southern Thailand but has since been reported in the adjoining countries of Cambodia and Laos. The viral examinations were intended to complement investigations on the disease initiated in 1982 by the staff at the National Inland Fisheries Institute (NIFI) in Bangkok, Thailand.

Although potentially pathogenic organisms were observed (e.g. fungal and protozoan agents) or cultured (e.g. Aeromonas hydrophila, Pseudomonas sp., Myxobacteria) from the diseased fish, the etiology of the condition has yet to be established.

Losses were greatest among fish populations following periods of rainfall when peak run-off from agricultural areas occurred. This led investigators at NIFI to suspect that the wide use of pesticides was acting to predispose fish to the ulcer disease outbreaks. More than 10 different pesticides have been detected in samples of water collected from ponds (Boonyaratapalin 1983).

Although the disease was observed in several

\footnotetext{
- Adressee for correspondence
}

species of fish, those most noticeably affected were the cultured snakehead Ophicephalus striatus, the walking catfish Clarias batrachus, and the sand goby $O x y$ eleotris marmoratus

A new virus was isolated during the course of an examination of wooden cage cultured sand gobies with ulcer disease from the Chaophya River, Ayudhaya Province, Thailand. The virus is a member of the Birnaviridae which include representatives from several aquatic animals (Dobos et al. 1979). This report describes the characteristics of the first virus to be isolated from fish in Thailand and the first from sand goby. In addition, the serological, phenotypic and biochemical characteristics of this virus differed from those of previously described strains in the Birnaviridae.

\section{MATERIALS AND METHODS}

Cell lines. Six established fish cell lines were used in this study: (1) the CHSE-214 line (ATCC CRL 1681) from chinook salmon Oncorhynchus tshawytscha (Lannan et al. 1984); (2) the BF-2 line (ATCC CCL 91) derived from bluegill Lepomis macrochirus; (3) the BB line (ATCC CCL 59) from brown bullhead Ictalurus nebulosus; (4) EPC from common carp Cyprinus carpio; (5) the RTG-2 line (ATCC CCL 55) from rainbow trout Salmo gairdneri; and (6) the FHM line (ATCC 
CCL 42) from fat head minnow Pimephales promelas. These 6 cell lines are listed, and their origins summarized, by Wolf \& Mann (1980). All lines were propagated in minimal essential medium (MEM) supplemented with Earle's salts, fetal bovine serum (5\% $\mathrm{v} / \mathrm{v}), 2 \mathrm{mM}$ L-glutamine, $50 \mu \mathrm{g} \mathrm{\textrm {ml } ^ { - 1 }}$ streptomycin and $50 \mathrm{IU} \mathrm{m \textrm {m } ^ { - 1 }}$ penicillin. For routine cell propagation the CHSE-214 and RTG-2 lines were incubated at $20^{\circ} \mathrm{C}$ and the BF-2, BB, FHM and EPC lines at $25^{\circ} \mathrm{C}$.

Viruses. The characteristics of the 3 strains of infectious pancreatic necrosis virus (IPNV) of the family Birnaviridae used in this study have been described previously (Hedrick et al. 1983a, b). The virus from sand goby (SGV) was isolated from diseased cage-cultured fish sampled in March of 1984 by 3 of the authors (R.P.H., J.L.F. and S.B.j. Kidney and spleen samples were prepared for inoculation onto cell lines as described by McDaniel (1979). Primary isolations of SGV were made on FHM, EPC and BF-2 lines. All subsequent stocks, including the virus used in serological and biochemical tests, were propagated in CHSE214 cells. Reovirus type 3 (Dearing strain) was grown in $\mathrm{L}$ cells at $37^{\circ} \mathrm{C}$ and was used for double-stranded (ds) RNA molecular weight estimates.

Host cell specificity and growth temperature. The SGV and 3 reference strains of IPNV were examined for their ability to induce cytopathic effects (CPE) in 6 selected fish cell lines. In addition, the effects of temperature on virus replication were determined at 20,25 and, where possible, $30^{\circ} \mathrm{C}$.

Monolayer cultures of CHSE-214, RTG-2, BF-2, BB, FHM and EPC cells in 24 -well dishes (Linbro Co.) were inoculated with each virus at a multiplicity of infection (MOI) of 0.1 to 1.0 . Following a $30 \mathrm{~min}$ adsorption, $1.0 \mathrm{ml}$ of MEM with $5 \%$ fetal bovine serum containing $0.015 \mathrm{M}$ pH 7.4 HEPES (N-2-hydroxyethylpiperazine$\mathrm{n}^{\prime}$-2-ethanesulfonic acid) was added. The cells were examined daily for the appearance of CPE over a period of $7 \mathrm{~d}$ at 20,25 , and $30^{\circ} \mathrm{C}$. CHSE-214 and RTG-2 cultures were not tested at $30^{\circ} \mathrm{C}$ because this temperature is lethal to these cell lines. The amounts of virus released from infected BF-2 cell cultures were also determined in growth studies conducted at 5, 10, 20,25 and $30^{\circ} \mathrm{C}$. The amounts of SGV produced in the $\mathrm{BF}-2$ cell cultures were determined by $\mathrm{TCID}_{50}$ analysis on CHSE- 214 cells at $20^{\circ} \mathrm{C}$. For comparative purposes, the yields of VR-299 IPNV virus in BF-2 cells were determined in parallel.

Neutralization tests. The serological relatedness of SGV to the IPNV reference strains VR-299, SP, and AB was made by cross-neutralization tests using hyperimmune rabbit sera prepared against each of the 4 viruses. The antisera were prepared, and the neutralization tests performed, as described by Okamoto et al. (1983). The method of Archetti \& Horsfall (1950) was used to estimate the serological relatedness of the viruses.

Immunoprecipitation of virion polypeptides. The virion polypeptides from each of the viruses were examined following their immunoprecipitation from crude ${ }^{35}$ S-methionine labeled cell lysates. Monolayers of CHSE-214 cells prepared in 24-well dishes were rinsed twice with methionine-free MEM and then incubated in the same medium for $4 \mathrm{~h}$. The medium was then removed and the cells inoculated at a $\mathrm{MOI}$ of 1 to 10 with virus suspended in Earle's balanced salt solution (BSS). After a $30 \mathrm{~min}$ adsorption period, $0.5 \mathrm{ml}$ of $\mathrm{MEM}$ containing $10 \mu \mathrm{Ci}$ of ${ }^{35} \mathrm{~S}$-methionine was added to each well. The inoculated cells were then incubated at $20^{\circ} \mathrm{C}$ for $4 \mathrm{~d}$ or until CPE was complete. Uninoculated celis (no virus), labeled in the same manner, were included as controls.

The cells or cell debris and supernatants from control and experimental (virus-infected) wells were collected and centrifuged for $3 \mathrm{~min}$ at $15000 \mathrm{rpm}$ in a microfuge (Beckman Instruments Inc.). The clarified supernatants $(300 \mu \mathrm{l})$ were then removed and $20 \mu \mathrm{l}$ of hyperimmune serum (antiVR-299 IPNV) was added to each.

The antigen-antibody complexes were allowed to form at $4{ }^{\circ} \mathrm{C}$ overnight and were then removed by the addition of $20 \mu \mathrm{l}$ of a $40 \%(\mathrm{v} / \mathrm{v})$ suspension of protein A-Sepharose CL-4B (LKB) in extraction buffer (nonidet NP $401 \%$, phenylmethylsulfonyl fluoride $0.1 \mathrm{mM}$, in phosphate buffered saline, $\mathrm{pH} 8.0$ ). After 2 h incubation, the protein A-Sepharose beads and bound antigen-antibody complexes were pelleted by centrifugation in a microfuge $(15000 \mathrm{rpm})$ for $5 \mathrm{~min}$. The beads were washed 3 times in extraction buffer and then $30 \mu \mathrm{l}$ of double-strength sodium dodecyl sulfate (SDS) sample buffer (Laemmli 1970) was added. The preparations were boiled for $2 \mathrm{~min}$ and then analyzed for the liberated polypeptides, as described below, on $9 \%$ polyacrylamide gels (PAGE).

The ${ }^{35} \mathrm{~S}$-methionine-labeled (30000 counts per lane) polypeptides were examined after $4 \mathrm{~h}$ of electrophoresis at $12 \mathrm{~mA}$. The polypeptide bands were stained with $1 \%$ Coomassie Brilliant Blue, following which the gels were dried and applied to 'non-screen' $X$-ray film (Eastman Kodak Inc.). The film was developed after 3 to $5 \mathrm{~d}$ and then superimposed over the dried gel to determine how the radioactive bands lined up with the stained molecular weight markers and the polypeptides of VR-299, SP, and AB IPNV, prepared from purified virions.

Virion RNA analysis. The RNA segments of SGV and the reference strains of IPNV were extracted and analyzed in polyacrylamide gels. The culture fluid from infected CHSE-214 cells grown in $25 \mathrm{~cm}^{2}$ flasks (Corning Co.) was centrifuged at $2000 \times \mathrm{g}$ for $10 \mathrm{~min}$ to remove cellular debris and then sodium $\mathrm{N}$-lauroylsar- 
cosine (Sigma Chemical Co.) was added to a final concentration of $0.1 \%(\mathrm{w} / \mathrm{v})$ to the supernatant fraction. The virions were sedimented by centrifugation at $130000 \times \mathrm{g}$ for $45 \mathrm{~min}$, the pellet was resuspended in $0.1 \mathrm{ml}$ TNE buffer $(0.01 \mathrm{M}$ Tris, $0.1 \mathrm{M} \mathrm{NaCL}, 0.001 \mathrm{M}$ EDTA, pH 7.5), and SDS was added to a final concentration of $0.5 \%$. Proteinase K (Sigma Chemical Co.) was then added (final concentration $200 \mu \mathrm{g} \mathrm{ml}^{-1}$ ) and digestion was allowed to proceed at $37^{\circ} \mathrm{C}$ for $1 \mathrm{~h}$ following which $0.1 \mathrm{ml}$ of SDS sample buffer (Laemmli 1970) was added. The preparation was stored at $-80^{\circ} \mathrm{C}$ until analyzed. For analysis, the samples were placed in a boiling water bath for $1 \mathrm{~min}$. They were then loaded into $9 \%$ acrylamide gels (Laemmli 1970) and after $22 \mathrm{~h}$ of electrophoresis at $9 \mathrm{~mA}$ (gel length $12.3 \mathrm{~cm}$, gel thickness $0.75 \mathrm{~mm}$ ) the separated RNA segments were stained with silver as described by Merrill et al. (1981).

\section{RESULTS}

\section{Virus isolation}

Cytopathic effects (CPE) characteristic of IPNV were first observed in BF-2 and EPC cells at 25 and $30^{\circ} \mathrm{C}$ $48 \mathrm{~h}$ after inoculation with sand goby tissue extracts. A similar CPE occurred in FHM cells 1 d later. The supernatant from BF-2 cells showing CPE was harvested, passed through a $0.45 \mu \mathrm{m}$ pore diameter membrane filter, diluted 1000-fold in MEM without serum (MEM$0)$, and inoculated onto fresh monolayers of BF-2 cells. CPE was again observed. Stocks of the virus were prepared after 3 consecutive passages and frozen at $-70^{\circ} \mathrm{C}$. Morphology and size of the virions of SGV were indistinguishable from IPNV strains when observed by electron microscopy (Fig. 1). The distinctive morphology of the virions and the characteristic CPE suggested that SGV was a birnavirus.

\section{Cell specificity and incubation temperature}

SGV, VR-299 and SP IPNV replicated in the EPC, FHM, BB, BF-2, RTG-2 and CHSE-214 cell lines at 20 and $25^{\circ} \mathrm{C}$ as indicated by complete destruction of the cell monolayers. Although AB IPNV replicated at 20 and $25^{\circ} \mathrm{C}$ in the BB, BF-2, RTG-2, and CHSE-214 lines, no CPE was observed in either the EPC or FHM cell lines. In contrast to the reference strains, SGV grew at $30^{\circ} \mathrm{C}$ in the EPC, FHM, BB, and BF-2 cell lines (this temperature is lethal to RTG-2 and CHSE-214 cells). A more detailed comparison of VR-299 IPNV and SGV growth showed that both viruses replicated well at temperatures from 5 to $25^{\circ} \mathrm{C}$. At $30^{\circ} \mathrm{C}$, however, no release of virus into the culture medium was detected with VR-299 IPNV infected BF-2 cells. In contrast, BF-2 cells infected with SGV released up to $10^{8.9} \mathrm{TCID}_{50} \mathrm{ml}^{-1}$ of virus at $30^{\circ} \mathrm{C}$ (Fig. 2).

\section{Serological comparisons}

Cross-neutralization studies with antisera to the 3 reference strains of IPNV and SGV showed that SGV was related to but distinct from VR-299, SP, and AB IPNV (Table 1). Using approximately the same concentration of SGV and $A B$ IPNV, the anti-AB IPNV serum was nearly 20 times more effective in neutraliz-
Fìg. 1. Electron micrograph of partially purified virions of sand goby virus (SGV) stained with $2 \%$ phosphotungstic acid

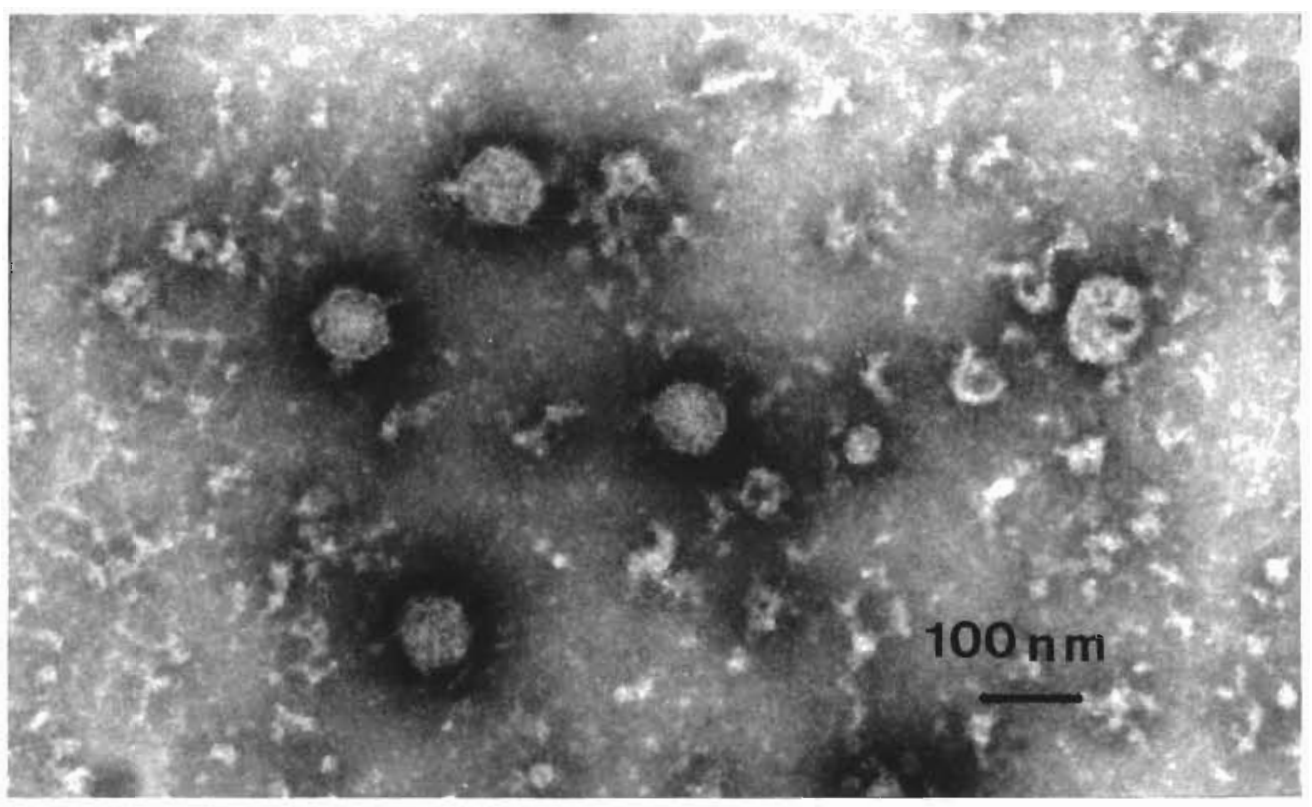




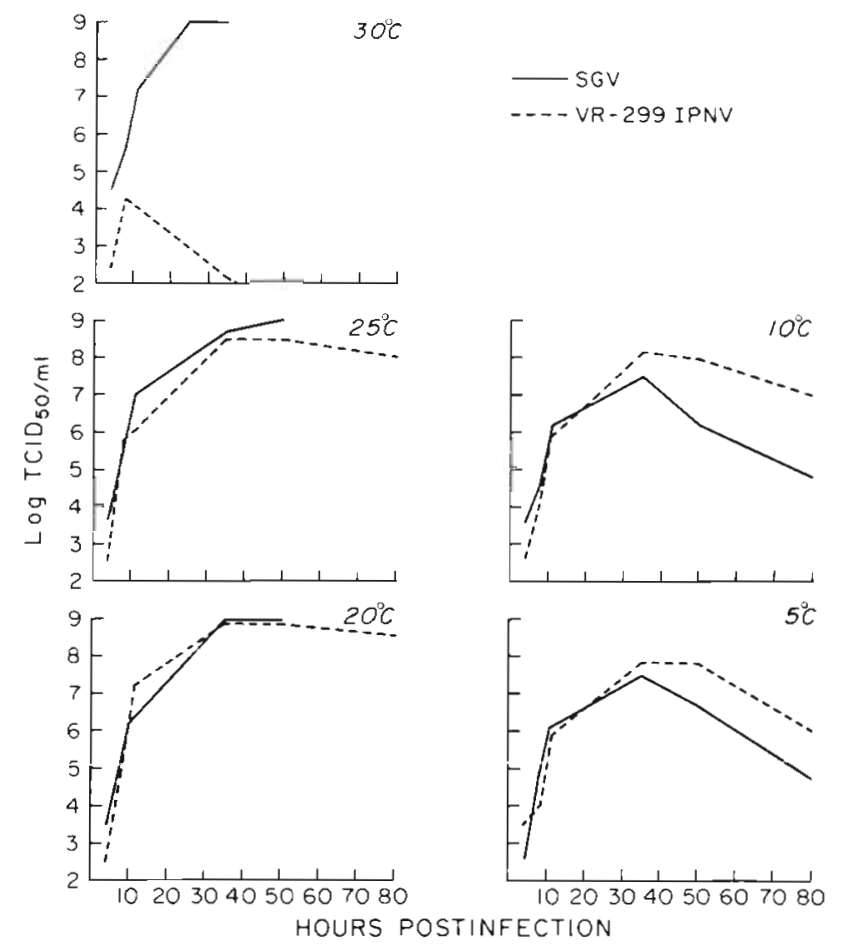

Fig. 2. Average concentrations of virus released into the culture medium of BF-2 cells infected with sand goby virus (SGV) or VR-299 IPNV and incubated at selected temperatures. Amount of virus in duplicate $25 \mathrm{~cm}^{2}$ flasks was determined by $\mathrm{TCIO}_{50}$ analysis on CHSE- 214 cells at $20^{\circ} \mathrm{C}$

ing the homologous virus. This suggested that SGV and $A B$ IPNV were antigenically substantially different from each other, the difference being as great as those occurring among the 3 reference viruses (e.g. SP IPNV compared to AB IPNV). The relatedness values of Archetti \& Horsfall (1950) showed that SGV was least related to VR-299 IPNV (a large $1 / \mathrm{r}$ value) and that it was approximately equally but distantly related to SP and $A B$ IPNV.

\section{Biochemical properties}

The RNA segments and polypeptides of SGV were compared with those of the reference strains in acrylamide gels. The SGV contained 2 segments of high molecular weight ds RNA. The mobilities of both segments were similar to those of VR-299 IPNV but differed from those of the other reference strains (Fig. 3).

The virion polypeptides precipitated with VR-299 IPNV serum showed that each of the reference viruses and SGV possessed 3 size classes of proteins ( $\alpha$, heavy; $\beta$, middle; $\gamma$, light) (Fig. 4). When virus culture supernatants served as the source of the viral polypeptides, each virus yielded $3 \beta$-polypeptides (these showed up between the $45 \times 10^{3}$ to $66 \times 10^{3} \mathrm{MW}$ markers). The fastest migrating $\beta$-polypeptide found for edch virus corresponded to the only polypeptide found when the homologous purified virus was the polypeptide source. The positions of the $\beta$-polypeptides derived from the purified viruses are shown by arrows in Fig. 4 .

\section{DISCUSSION}

Infectious pancreatic necrosis virus (IPNV) was the first birnavirus isolated from fish. The virus was named IPNV because when isolated by Wolf (1966) it was found to reproduce the disease described by Wood et al. (1955) as infectious pancreatic necrosis (IPN) in trout. Viruses with physical and serological properties in common were also isolated from trout in Europe (Wolf \& Quimby 1971). However, it is now apparent that many species of fish and shellfish can be suitable hosts for similar viruses (Adair \& Ferguson 1981, Hill 1982) even though the pathology characteristic of IPN may be lacking.

Many birnaviruses have now been isolated from fish in the Orient (Sano 1971, Hedrick et al. 1983a, b,

Table 1. Serological relations of sand goby virus (SGV) to 3 reference strains of infectious pancreatic necrosis virus (IPNV) by serum cross-neutralization tests

\begin{tabular}{|c|c|c|c|c|}
\hline \multirow[t]{2}{*}{ Virus } & \multicolumn{4}{|c|}{ Antiserum } \\
\hline & SGV & VR-299 IPNV & SP IPNV & $A B$ IPNV \\
\hline $\operatorname{SGV}(629)^{a}$ & $19200^{b}(1.0)^{c}$ & $480(54.0)$ & $1520(15.0)$ & $1440(16.5)$ \\
\hline VR-299 IPNV (729) & 314 & $22656 \quad(1.0)$ & $2128(26.0)$ & $752(37.2)$ \\
\hline SP IPNV $(400)$ & 1200 & 334 & $21376 \quad(1.0)$ & $1416(15.5)$ \\
\hline AB IPNV (500) & 1504 & 670 & 1920 & $30720 \quad(1.0)$ \\
\hline \multicolumn{5}{|c|}{$\begin{array}{l}\text { Amount of virus used in each test, expressed at } \mathrm{TCID}_{50} \\
\text { "Reciprocal of the serum dilution giving protection to } 50 \% \text { of the test cultures } \\
\text { "The } 1 / \mathrm{r} \text { value as described by Archetti \& Horsfall (1950) } \mathrm{r}=\sqrt{\mathrm{r}_{1} \times \mathrm{r}_{2}} \text { with } \\
\qquad r_{1}=\frac{\text { reciprocal of dilution of antiserum to Virus (1) neutralizing Virus (2) }}{\text { reciprocal of serum dilution of Virus (1) neutralizing Virus (2) }} \\
\text { and } r_{2}=\frac{\text { reciprocal of dilution of antiserum to Virus (2) neutralizing Virus (1) }}{\text { reciprocal of dilution of antiserum to Virus (2) neutralizing Virus (2) }}\end{array}$} \\
\hline
\end{tabular}




\section{灾}

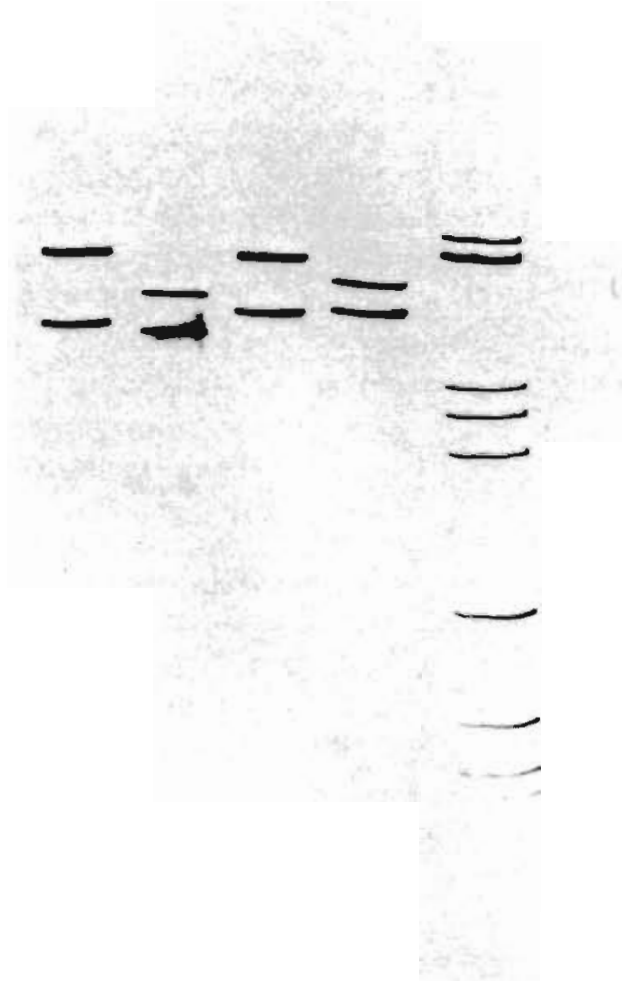

Fig. 3. A comparison of the ds RNA genome segments of sand goby virus (SGV) with those of 3 reference strains of infectious pancreatic necrosis virus is shown in a $9 \%$ acrylamide slab gel. Samples were applied to the top of the gel (labeled SGV, VR etc.) and direction of migration was downward. Electrophoresis for $22 \mathrm{~h}$ at $9 \mathrm{~mA}$ was followed by silver staining according to Merrill et al. (1981). Reovirus 3 genome segments were included as ds RNA molecular weight markers in the same gel

Hedrick et al. 1985), and most are closely related to the AB serogroup of IPNV originally described by Jorgensen \& Grauballe (1971) from trout in Denmark. In some cases, it seems reasonable to assume that the AB IPNV strains were imported into the Orient with shipments of fish or eggs from Europe (Sano et al. 1981, Hedrick et al. 1983b). However, our recent isolations of similar viruses from populations of fish in Taiwan and in the present case, Thailand (SGV), suggest that this may not always be the case. The isolates from Taiwan and Thailand are probably indigenous to these countries. They display properties, including the ability to grow at $30^{\circ} \mathrm{C}$, not previously described for isolates of the aquatic birnaviruses. These properties distinguish them from other known birnaviruses from fish and suggest that they had a warm water origin. This has led us to examine in more detail the phenotypic, serological, and biochemical characteristics of SGV.

Although we have isolated and characterized birnaviruses from Japan, Taiwan and Korea (Hedrick et al. 1983a, b, 1985), SGV was the first agent that induced CPE when incubated at $30^{\circ} \mathrm{C}$. We have since examined 109 aquatic birnavirus isolates collected from Europe, North America and the Orient and find that certain of these from eels Anguilla japonica and loach Cobitis sp. from Southern Taiwan replicate efficiently at $30^{\circ} \mathrm{C}$ in the EPC, BB and BF-2 cell lines (S. N. Chen, National Taiwan University, pers. comm., unpubl. data). The ability to replicate in these warm water fish hosts at $30^{\circ} \mathrm{C}$ may allow survival of these viruses during extended periods when water temperatures are elevated.

The serological comparison of SGV with reference strains of IPNV showed that the virus was clearly unique (Table 1). We have found several apparent $A B$ IPNV types in non-salmonid fish from Taiwan and Japan (Hedrick et al. 1983a, b). These viruses were strongly neutralized by anti-AB IPNV serum and showed phenotypic properties similar to AB IPNV such as the inability to replicate in the EPC or FHM cell lines. In contrast, SGV replicated well in both of these lines and at $30^{\circ} \mathrm{C}$

The $1 / r$ values are a convenient method for quantitatively measuring antigenic relatedness of viruses in cross-neutralization studies (Archetti \& Horsfall 1950). A value of 1.0 indicates complete homology and increasing values indicate greater antigenic unrelatedness. In our study, SGV was shown to be least related to VR-299 IPNV and 1/I values indicated it to differ from SP and AB IPNV to an extent equal to that for the differences found among the 3 reference strains.

The analytical techniques used for determining the RNA and polypeptide composition of the virions provided evidence to support the conclusion that the viruses were different and permitted the characterization of the viruses using very small volumes of material. These techniques are more rapid and less time-consuming than growing large volumes of virus for biochemical comparisons. Immunoprecipitation of polypeptides from culture supernatants with polyclonal rabbit serum results in banding patterns of polypeptides that differ from those resulting from purified virus, apparently because precursor molecules present in the supernatant fraction are also detected (Fig. 4). This is particularly true for the $\beta$-species polypeptides that usually show 3 polypeptides of differing molecular weight, the lightest of which corresponds to the (single) structural protein found in purified virions. 


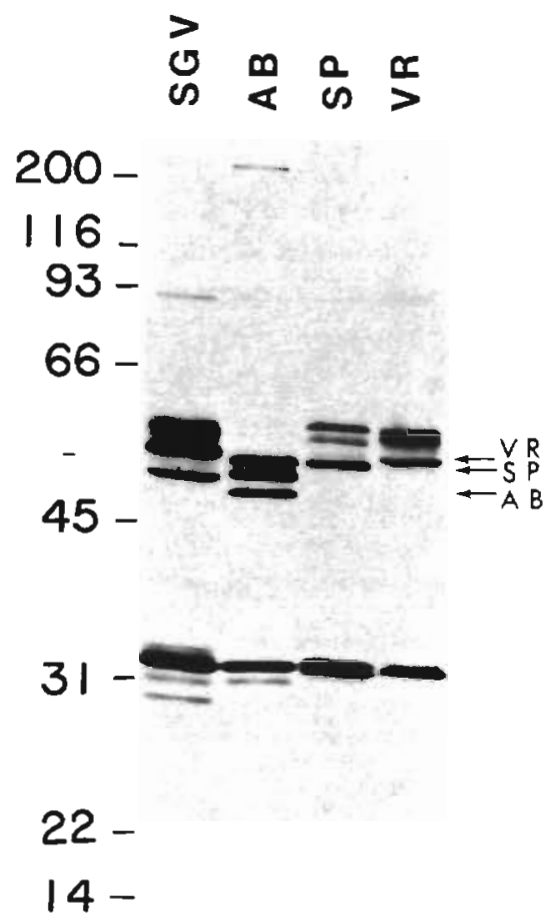

Fig. 4. A comparison of the virus-specific polypeptides of sand goby virus (SGV) with those of 3 reference strains of infectious pancreatic necrosis virus (IPNV) is shown in a $9 \%$ acrylamide gel. The ${ }^{35} \mathrm{~S}$-methionine labeled polypeptides were recovered by immunoprecipitation from infected cell lysates with antisera to strain VR-299 IPNV (details in text). Positions of polypeptides after $4 \mathrm{~h}$ of electrophoresis at $12 \mathrm{~mA}$ were determined following drying and exposure to $X$-ray film. The $\beta$-polypeptides of all 4 viruses immunoprecipitated from infected cell lysates were found in the 46 to $60\left(\times 10^{3}\right)$ molecular weight range. Because precursor peptides as well as the final cleavage product (the fastest migrating $\beta$-species) are precipitated with anti-virus antibody, several (usually 3 ) bands were observed in the 46 to $60 \times 10^{3}$ molecular weight range for each virus. The positions of the molecular weight markers $\left(\times 10^{3}\right)$ are shown on the left by horizontal bars; the capsid $\beta$-polypeptides from purified virions of the 3 reference strains (shown at right by arrows) were determined by Coomassie Brilliant Blue staining

The sizes of the $\beta$-precursor polypeptides for VR-299 IPNV shown by immunoprecipitation in our studies agreed well with those reported by Dobos (1977) and Dobos \& Rowe (1977), who examined the sequential polypeptide synthesis in pulse-chase experiments.

The polypeptide immunoprecipitation studies also provide some insight into the cross-reactions observed between virus strains during neutralization and to the relatedness of polypeptides that may not be involved in neutralization. We found that antisera prepared against AB, VR-299 or SP IPNV precipitated polypep- tides of each virus equally well (data not shown). This demonstrates that the viruses all share homologous regions on certain structural polypeptides although significant changes in areas associated with virus neutralization have occurred. The technique for strain comparison is also simplified, because all polypeptides, even those from viruses in different serogroups, appear to be precipitated with a single anti-serum (unpubl. data).

The genome comparisons showed that SGV contained 2 segments of high molecular ds RNA similar in size to those of VR-299 IPNV but clearly different to those of SP and AB IPNV (Fig. 3). In our experience, the mobility of the RNA segments for related strains is less diagnostic than comparisons made by neutralization and polypeptide composition. RNA comparisons, however, aid in distinguishing some strains within the same serogroup.

Although we now know that SGV differs from previously described fish birnaviruses, we have yet to establish its role in the ulcer disease now plaguing fish in Thailand. There are indications that SGV is related to another birnavirus isolated from loach in Taiwan. The latter virus is pathogenic to loach, carp and tilapia Sarotherodon nilotica but does not cause signs similar to ulcer disease observed in cultured fish of Thailand (S. N. Chen, National Taiwan University, pers. comm.). Further studies on the effect of SGV in experimentally infected fish are planned and should aid in our understanding of the relation of the virus to the ulcer disease condition. A more comprehensive viral examination of the other fish species with ulcer disease should also be conducted to further evaluate the role of SGV in the etiology of this disease.

Acknowledgements. The authors thank NOAA Office of Sea Grant, Department of Commerce, under Grant Nos. NA 80 AAD 102-R/A-45 and NA 79 AAD-00106 for providing support for these studies. This work was funded by USAID in Thailand. Oregon Agricultural Experiment Station Technical Paper No. 7461 .

\section{LITERATURE CITED}

Adair, B. M. Ferguson, H. W. (1981). Isolation of infectious pancreatic necrosis (IPN) virus from non-salmonid fish. J. Fish Dis. 4: 69-76

Archetti, I., Horsfall, F. L. (1950). Persistent antigenic variation in influenza A viruses after incomplete neutralization in vivo with heterologous immune serum. J. exp. Med. 92: 441-462

Boonyaratapalin, S. (1983). Fish disease outbreak in Thailand, late 1982-early 1983. Technical paper no. 19. National Inland Fisheries Institute, Bangkhen, Bangkok, Thailand

Dobos, P. (1977). Virus-specific protein synthesis in cells infected by infectious pancreatic necrosis virus. J. Virology $21: 242-258$ 
Dobos, P., Rowe, D. (1977). Peptide map comparison of infectious pancreatic necrosis virus-specific polypeptides. J. Virology 24: 805-820

Dobos, P., Hill, B. J., Hallet, R., Kells, D. T. C., Becht, H., Teninges, D. (1979). Biophysical and biochemical characterization of five animal viruses with double-stranded RNA genomes. J. Virology 32: 593-605

Hedrick, R. P., Okamoto, N., Sano, T., Fryer, J. L. (1983a). Biochemical characterization of eel virus European. J. gen. Virology 64: 1421-1426

Hedrick, R. P., Fryer, J. L., Chen, S. N., Kou, G. H. (1983b). Characteristics of four birnaviruses isolated from fish in Taiwan. Fish Pathol. 18: 91-97

Hedrick, R. P., Eaton, W. D., Fryer, J. L., Hah, Y C., Park, J. W., Hong, S. W. (1985). Biochemical and serological properties of birnaviruses isolated from fish in Korea. Fish Pathol. 20: 463-468

Hill, B. J. (1982). Infectious pancreatic necrosis virus and its virulence. In: Roberts, R. J. (ed.) Microbial diseases of fish. Academic Press, London, p. 91-114

Jorgensen, P. E. V., Grauballe, P. C. (1971). Problems in the typing of IPN virus. Acta. Vet. Scand. 12: 145-147

Laemmli, U. K. (1970). Cleavage of the structural proteins during the assembly of the head of bacteriophage $\mathrm{T} 4$. Nature, Lond. 227: 680-685

Lannan, C. N., Winton, J. R., Fryer, J. L. (1984). Fish cell lines: Establishment and characterization of nine cell lines from salmonids. In Vitro 20: 671-676

McDaniel D. (1979). Procedures for the detection and identification of certain fish pathogens. American Fisheries Society, Fish Health Section, Bethesda, Maryland
Merrill, C. R., Goldman, D., Sedman, S. A., Ebert, M. H (1981). Ultrasensitive stain for proteins in polyacrylamide gels shows regional variation in cerebrospinal fluid proteins. Science 211: 143-144

Okamoto, N., Sano, T., Hedrick, R. P., Fryer, J. L. (1983). Antigenic relationships of selected strains of infectious pancreatic necrosis virus (IPNV) and eel virus European (EVE). J. Fish Dis. 6: 19-26

Sano, T. (1971). Studies on viral diseases of Japanese fishes II. Infectious pancreatic necrosis of rainbow trout: Pathogenicity of the isolants. Bull. Jap. Soc. scient. Fish. 37: $495 \cdot 498$

Sano, T., Okamoto, N., Nishimura, T. (1981). A new viral epizootic of Anguilla japonica Temmick and Schlegel. J. Fish Dis. 4: 127-139

Wolf, K. (1966). Infectious pancreatic necrosis (IPN) of salmonid fishes. U.S. Department of Interior, Bureau of Sport Fisheries and Wildlife, Fish Disease Leaflet 1: 1-4

Wolf, K., Quimby, M. C. (1971). Salmonid viruses: infectious pancreatic necrosis virus. Morphology, pathology and serology of first European isolates. Arch. gesamt. Virusforschung 24: 144-150

Wolf, K., Mann, J. A. (1980). Poikilotherm vertebrate cell lines and viruses. A current listing for fishes. In Vitro 16: 168-179

Wood, E. M., Snieszko, S. F., Yasutake, W. T. (1955). Infectious pancreatic necrosis in brook trout. A.M.A. Arch. Pathol. 60: 26-28 